\title{
Carbon mineralization in acidic soils amended with an organo-mineral bentonite waste
}

\author{
Isabel Rodríguez-Salgado, Paula Pérez-Rodríguez, Vanesa Santás, Juan Carlos Nóvoa- \\ Muñoz, Manuel Arias-Estévez, Montserrat Díaz-Raviña, David Fernández-Calviño*
}

Department of Plant Biology and Soil Science, Section of Soil Science, University of Vigo, 32004 Ourense, Spain. ${ }^{2}$ Instituto de Investigaciones Agrobiológicas de Galicia, IIAG-CSIC, Santiago de Compostela, Spain.*Corresponding author: davidfc@uvigo.es.

\begin{abstract}
Bentonite based organic-mineral wastes contains high concentrations of organic matter and plant nutrients and hence presents a high potential as a soil amendment. However, it also can have high salinity and high copper concentrations that may cause negative effects on microorganisms when the soil is amended with this type of wastes. In this work, the effect of soil amendment with a bentonite based winery waste on soil carbon mineralization was studied in acidic vineyard soils as an indicator of soil quality. The carbon mineralization in the waste is significantly lower and slower than that in the studied vineyard soils despite its significantly higher amount of organic carbon. However, when the bentonite winery waste was added to the soils, the carbon mineralization showed positive priming effects (increased between 78 and 337\%). Therefore, reductions in the carbon mineralization, and hence changes on short-term organic matter turnover are not expected after bentonite waste amendment in acid soils.
\end{abstract}

Keywords: Bentonite, waste, organic matter, mineralization, microorganisms, soil

\section{Introduction}

The use of bentonite in the food industry is very common worldwide, especially in the wineries and edible oil refineries, generating big amounts of wastes rich in clays and organic matter. However, these types of organo-mineral wastes were little studied yet (Loh et al., 2017). These types of wastes generally have high amounts of organic matter and plant nutrients such as $\mathrm{K}, \mathrm{Ca}$ or P. Therefore, they may be used as soil amendments to increase organic matter and nutrient contents in soils (Loh et al., 2017). However, these wastes may have important drawbacks as amendments because there may be high concentrations of salts and heavy metals, especially those originated in the wineries (Fernández-Calviño et al., 2015). Therefore, the uncontrolled application of these wastes to the soil may negatively affect soil micro- 
bial communities and hence soil ecosystems because they play a key function in ecosystem processes such as decomposition, nutrient cycling and plant symbioses (Nannipieri et al., 2003).

One indicator of soil quality from a microbiological point of view is the soil organic carbon mineralization (Thomsen et al., 2012), a parameter related to longterm soil fertility. Therefore, studies on organic matter amendments are common and important. Organic carbon mineralization has been studied in soils amended with different types of winery wastes (Bustamante et al., 2007, 2010; Mosse et al, 2012). The effect of wastes and other organic matter sources application to the soil on organic carbon mineralization can be quite variable, and increases (Ginocchio et al., 2013; Hasbullah and Marschner, 2016) and decreases (Meli et al., 2002) have been reported. The short-term increases or decreases in soil organic carbon mineralization caused by the organic matter amendments are defined as positive or negative priming effects (Kuzyakov et al., 2000). These priming effects can affect the organic matter turnover in the soil, and therefore, the study of organic carbon mineralization in the soil from different perspectives, such as the effects of amendments on microbial communities and on organic matter stabilization, is still an interesting research topic.

Wine clarification produces a solid waste rich in bentonite (a clay added to the wine) mixed with high amounts of organic matter and plant nutrients such as phosphorus and potassium (Arias-Estévez et al., 2007; Rodríguez-Salgado et al., 2014). These characteristics make bentonite wastes a promising soil amendment. However, this waste also contains high concentrations of copper, and its addition to soils in high doses can lead to an excessive increase in soil $\mathrm{pH}$ (Fernández-Calviño et al., 2015). Also, the addition of clays to the soil can reduce the $\mathrm{C}$-mineralization in the soil (Pal and Marschner, 2016) Therefore, the application of this waste to the soil should be performed carefully to avoid negative effects on soil microorganisms and hence detrimental effects on the surrounding environment. Despite its potential risk for soil ecosystems, the effect of soil amendment with neither bentonite winery wastes nor other organo-mineral wastes on organic carbon mineralization has not yet been analysed.

The aim of this work is the evaluation, for first time, of organic matter mineralization in the soil in response to bentonite winery waste additions. To this, five soils with different physicochemical characteristics were amended with two different concentrations of bentonite winery waste under laboratory conditions, and the carbon mineralization was monitored for 21 days. In addition, the carbon mineralization kinetics were modelled and possible priming effects assessed.

\section{Materials and Methods}

\subsection{Soils and bentonite winery waste characteristics}

The bentonite winery waste was supplied by Adegas Cunqueiro S.L. (Castrelo de Miño, Ourense, Spain). The bentonite used for wine clarification was a sodium montmorillonite, and after this process it became a solid waste rich in clay and organic matter. Once in the laboratory, the bentonite waste was air dried, sieved $(1 \mathrm{~mm})$ and stored in polypropylene jars prior to analysis or addition to the soils. For soil sampling, five vineyard plots were selected in a wine-growing area (Denomination of Origin O Ribeiro). In each vineyard, 20 soil sub-samples were randomly collected at a depth of 0-20 cm and subsequently mixed into a single composite soil sample which was air-dried, sieved through a 2-mm mesh and stored in polyethylene bottles. The proportions of sand (2-0.05 mm), silt $(0.05-0.002 \mathrm{~mm})$ and clay $(<0.002 \mathrm{~mm})$ of the soils were determined by wet sieving for the size fractions $>0.05 \mathrm{~mm}$ (sand) and using the international pipette 
method for those $<0.05 \mathrm{~mm}$ (silt and clay). For soils and the bentonite waste, the relevant chemical characteristics were determined as follows: the $\mathrm{pH}$ in water and $0.1 \mathrm{M} \mathrm{KCl}$ were measured at a solid/liquid ratio of 1:2.5 using a glass electrode connected to a $\mathrm{pH}$ meter, whereas the electrical conductivity was measured using a Crison 524 conductivity meter in filtered extracts obtained from 1:10 solid/liquid suspensions. Total carbon $(\mathrm{C})$ and total nitrogen $(\mathrm{N})$ contents were determined in finely milled samples using a Thermo Finnigan 1112 Series NC elemental analyser. The cation exchange capacity at soil $\mathrm{pH}(\mathrm{eCEC})$ was estimated as the sum of exchangeable base cations $(\mathrm{K}, \mathrm{Na}$, $\mathrm{Ca}$, and $\mathrm{Mg}$ ) extracted with $0.2 \mathrm{M} \mathrm{NH}_{4} \mathrm{Cl}$ (Sumner and Miller, 1996) and exchangeable aluminium (Al) was extracted with $1 \mathrm{M} \mathrm{KCl}$ (Bertsch and Bloom, 1996). Table 1 summarizes the general characteristics of the soils and bentonite waste.

Table 1. General characteristics (mean \pm standard errors) of 5 soils and bentonite waste

\begin{tabular}{|c|c|c|c|c|c|c|c|}
\hline & & S1 & S2 & S3 & S4 & S5 & BW \\
\hline $\mathrm{pH}$ & & $5.0 \pm 0.2$ & $5.0 \pm 0.1$ & $5.0 \pm 0.1$ & $6.2 \pm 0.3$ & $5.9 \pm 0.2$ & $6.0 \pm 0.1$ \\
\hline $\mathrm{pH}_{\mathrm{KCl}}$ & & $4.2 \pm 0.1$ & $3.9 \pm 0.1$ & $4.2 \pm 0.2$ & $5.1 \pm 0.3$ & $4.5 \pm 0.2$ & $5.7 \pm 0.2$ \\
\hline $\mathrm{EC}$ & $\mathrm{dS} \mathrm{m} \mathrm{m}^{-1}$ & $0.4 \pm 0.02$ & $0.1 \pm 0.01$ & $0.2 \pm 0.01$ & $0.1 \pm 0.00$ & $0.1 \pm 0.01$ & $19.7 \pm 1.2$ \\
\hline Sand & $\%$ & $45 \pm 1$ & $69 \pm 4$ & $68 \pm 5$ & $66 \pm 3$ & $70 \pm 5$ & - \\
\hline Silt & $\%$ & $3 \pm 2$ & $15 \pm 1$ & $20 \pm 3$ & $18 \pm 2$ & $18 \pm 2$ & - \\
\hline Clay & $\%$ & $22 \pm 2$ & $16 \pm 1$ & $12 \pm 1$ & $16 \pm 3$ & $12 \pm 1$ & - \\
\hline $\mathrm{C}$ & $\mathrm{g} \cdot \mathrm{kg}^{-1}$ & $45.1 \pm 3.8$ & $34.6 \pm 2.9$ & $24.6 \pm 1.7$ & $20.0 \pm 1.3$ & $7.3 \pm 0.5$ & $171.8 \pm 10.1$ \\
\hline $\mathrm{N}$ & $\mathrm{g} \cdot \mathrm{kg}^{-1}$ & $3.0 \pm 0.16$ & $2.5 \pm 0.18$ & $1.8 \pm 0.09$ & $1.7 \pm 0.11$ & $0.6 \pm 0.04$ & $20.1 \pm 1.00$ \\
\hline $\mathrm{C} / \mathrm{N}$ & & $15 \pm 0.3$ & $14 \pm 0.7$ & $14 \pm 1.0$ & $12 \pm 0.6$ & $12 \pm 0.4$ & $9 \pm 0.2$ \\
\hline eCEC & $\mathrm{l}_{\mathrm{c}} \mathrm{kg}^{-1}$ & $9.4 \pm 0.3$ & $3.6 \pm 0.2$ & $4.8 \pm 0.1$ & $9.8 \pm 0.2$ & $5.5 \pm 0.3$ & $170.5 \pm 3.1$ \\
\hline Total $\mathrm{Cu}$ & $\mathrm{mg} \mathrm{kg}^{-1}$ & $52 \pm 15$ & $214 \pm 20$ & $198 \pm 17$ & $168 \pm 21$ & $152 \pm 7$ & $1203 \pm 86$ \\
\hline
\end{tabular}

S: soil; BW: bentonite waste; $\mathrm{pH}$ : $\mathrm{pH}$ in water; $\mathrm{pHKCl}$ : $\mathrm{pH}$ in $0.1 \mathrm{M} \mathrm{KCl}$; $\mathrm{EC}$ : electrical conductivity; $\mathrm{C}$ : total carbon; $\mathrm{N}$ : total nitrogen; eCEC: effective cation exchange capacity

The selected soils were sandy loam or loam in texture, presented a narrow $\mathrm{pH}$ range (between 5.0 and 6.2 ), and a relatively high variation in total carbon content (7.3-45.1 $\left.\mathrm{g} \mathrm{kg}^{-1}\right)$. The electrical conductivity was low in all cases (non-saline), and the eCEC variable (3.6-9.8 $\left.\mathrm{cmol}_{\mathrm{c}} \mathrm{kg}^{-1}\right)$. The bentonite waste had a $\mathrm{pH}$ value (6.0) in the range found for soils. However, the total carbon $\left(172 \mathrm{~g} \mathrm{~kg}^{-1}\right)$, eCEC $\left(171 \mathrm{cmol}_{\mathrm{c}} \mathrm{kg}^{-1}\right)$ and salinity (strongly saline) were much higher in the bentonite waste than in the soils.

\subsection{Experimental design}

Three days before the experiment start, the soils and bentonite waste were rewetted until they were $80 \%$ saturated, which is long enough to recover the microbial community activity (Meisner et al., 2013). The soils were then mixed with two bentonite waste doses: a low waste dose that increased the original total soil organic carbon by $5 \%$ and a high waste dose that increased the original total soil organic carbon by $10 \%$, 
where the term 'original' refers to the initial total organic carbon content of the non-amended soils. These concentrations were selected because the resulted bentonite waste added to the soils was in the range of previous works where changes in the general soil characteristics in soils amended with bentonite wastes were analysed (Fernández-Calviño et al., 2015; Rodríguez-Salgado et al., 2017). These concentrations in the 5 studied soils cover a range where from no significant effects to significant effects on the general soil properties. Additionally, a control without bentonite waste was used for each soil. All mixtures were performed by quadruplicate and incubated in hermetic glass bottles under darkness at $28 \pm 2{ }^{\circ} \mathrm{C}$.

\section{3. $C$ mineralization measurement}

To measure $\mathrm{C}$ mineralization, a glass with $10 \mathrm{~mL}$ of $0.5 \mathrm{M} \mathrm{NaOH}$ solution was placed inside the hermetic glass bottles with soil and soil-waste mixtures and renovated at $2,4,6,8,11,14,17$, and 21 days. The $\mathrm{NaOH}$ extracts were then titrated against $\mathrm{HCl}$ to estimate $\mathrm{CO}_{2}$ released from soil. The $\mathrm{C}$ mineralization data were expressed with respect to the unit of total soil carbon in order to minimize the confounding influence of soil total soil organic carbon on $\mathrm{C}$ mineralization, as has been suggested for the study of microbiological parameters (Li et al., 2009).

\subsection{C mineralization modelling}

The special kinetic model (Bernal et al., 1998) was used to describe the $\mathrm{C}$ mineralization pattern from cumulative data of $\mathrm{C}$ mineralization. The special model (Equation 1) combines first-order with zeroorder mineralization models because it identifies the decomposition rates of an active pool (fast $\mathrm{C}$ mineralization pool) and a large resistant pool (slow $\mathrm{C}$ mineralization pool).

$$
C=C_{1}\left(1-e^{-k t}\right)+C_{2} k_{2} t \quad 1
$$

where $\mathrm{C}$ is the cumulative carbon amount mineralized at time $\mathrm{t}$ ( $\mathrm{mg} \mathrm{g}^{-1}$ soil carbon), $\mathrm{t}$ is the time from the beginning of the incubation (days), $\mathrm{C}_{1}$ and $\mathrm{C}_{2}$ are fast and slowly mineralizing $\mathrm{C}$ ( $\mathrm{mg} \mathrm{g}^{-1}$ soil carbon), respectively, and $\mathrm{k}$ and $\mathrm{k}_{2}$ are the fast and slow rate constants $\left(\right.$ day $\left.^{-1}\right)$.

\section{Results}

The $\mathrm{C}$ mineralization data (expressed as $\mathrm{mg} \mathrm{C}-\mathrm{CO}_{2}$ per gram of C) for the bentonite waste, five vineyard soils and 10 soil-bentonite waste mixtures are shown in the Figure 1. The carbon mineralization in the bentonite waste after 21 incubation days was $0.35 \mathrm{mg}$ of $\mathrm{C}-\mathrm{CO}_{2}$ per gram of organic carbon, which is significantly lower than the values for the nonamended soils (1.65-5.16 $\left.\mathrm{mg} \mathrm{g}^{-1}\right)$. However, when bentonite waste was added to the soils to increase the initial total soil organic $\mathrm{C}$ by $5 \%$, the $\mathrm{C}$ mineralization increased between 68 and $179 \%$, whereas when bentonite waste was added to the soils to increase its initial total content of organic $\mathrm{C}$ by $10 \%$, the $\mathrm{C}$ mineralization increased between 78 and 337\%.

Data from Figure 1 were fitted satisfactorily by the special model (Equation 1), explaining more than $99 \%$ of the experimental results in all cases (Table 2). The fast mineralizing $C\left(C_{1}\right)$ was lower than slowly mineralizing $\mathrm{C}\left(\mathrm{C}_{2}\right)$ in the bentonite waste, whereas in the soils the $\mathrm{C}_{1}$ was higher than $\mathrm{C}_{2}$ in all cases. When the bentonite waste was added to the soil $\mathrm{C}_{1}$ increased in response to the waste dose in all cases, whereas no clear response was found for $\mathrm{C}_{2}$. The fast rate constant $(\mathrm{k})$ and slow rate constant $\left(\mathrm{k}_{2}\right)$ were quite similar in the bentonite waste and studied soils, and therefore when the waste was added to the soils no clear tendencies were found. 

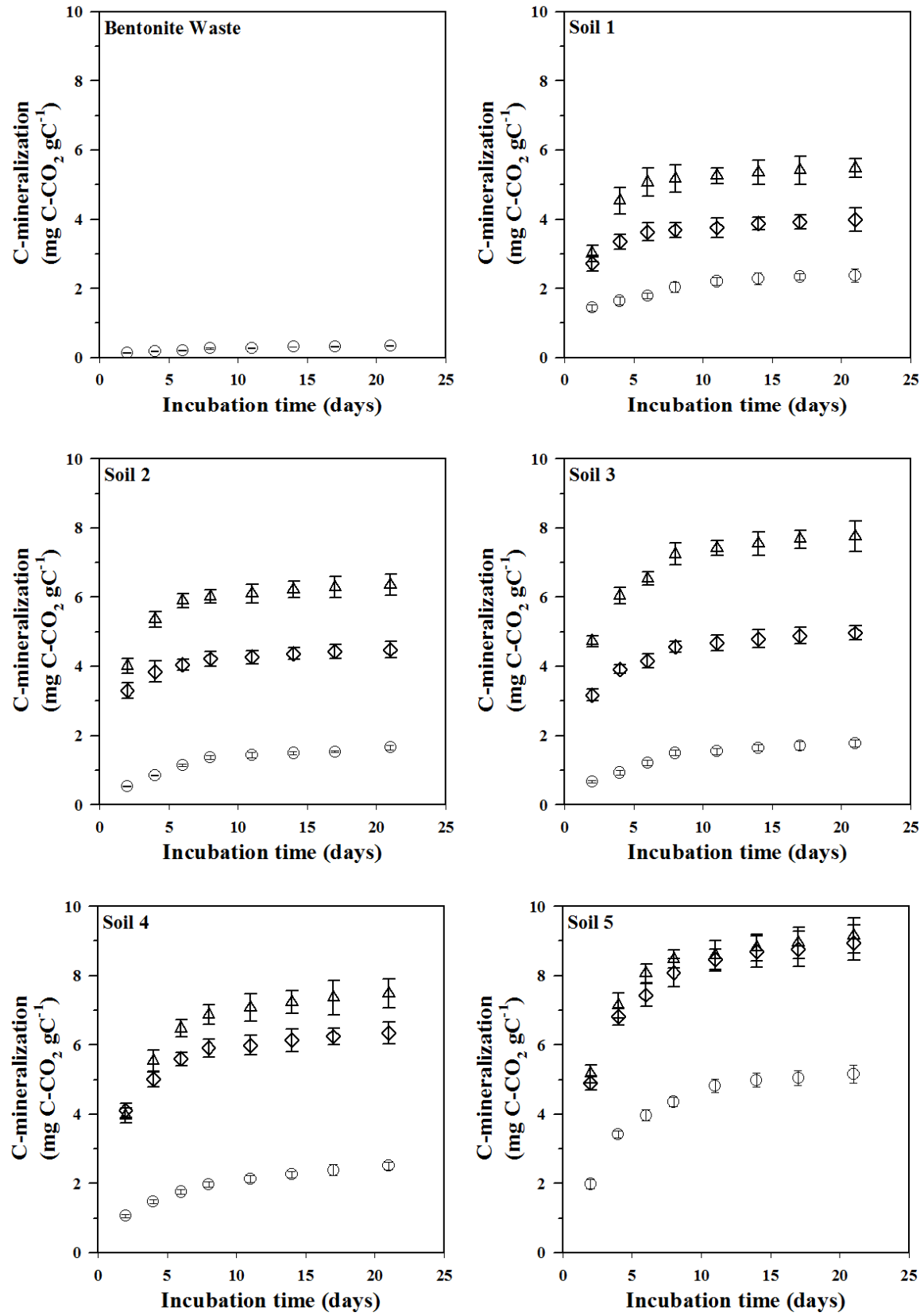

Figure 1. Cumulative C- $\mathrm{CO}_{2}$ evolution in bentonite waste, soils and amended soils. Non-amended soils or bentonite waste (circles); soils amended with a bentonite waste dose exhibited an increase in the original total soil organic carbon content by $5 \%$ (diamonds) and by $10 \%$ (triangles). The error bars show the standard errors. 
Table 2. Fitted parameters from the special kinetic model $\left(C=C_{1}\left(1-e^{-k t}\right)+C_{2} k_{2} t\right)$

\begin{tabular}{lcccccc}
\hline & $\mathrm{C}_{1}$ & $\mathrm{C}_{2}$ & $\mathrm{k}$ & $\mathrm{k}_{2}$ & $\mathrm{R}^{2}$ & $\mathrm{C}_{1} /\left(\mathrm{C}_{1}+\mathrm{C}_{2}\right)$ \\
\hline BW & $0.21 \pm 0.01$ & $0.64 \pm 0.01$ & $0.39 \pm 0.01$ & $0.01 \pm 0.00$ & 0.995 & 0.25 \\
S1 & $1.86 \pm 0.04$ & $1.19 \pm 0.08$ & $0.57 \pm 0.02$ & $0.02 \pm 0.00$ & 0.991 & 0.61 \\
S1+5\% & $3.58 \pm 0.04$ & $1.04 \pm 0.05$ & $0.68 \pm 0.02$ & $0.02 \pm 0.00$ & 0.999 & 0.77 \\
S1+10\% & $5.29 \pm 0.08$ & $0.69 \pm 0.02$ & $0.45 \pm 0.01$ & $0.01 \pm 0.00$ & 0.999 & 0.88 \\
S2 & $1.51 \pm 0.06$ & $0.61 \pm 0.01$ & $0.22 \pm 0.00$ & $0.01 \pm 0.00$ & 0.998 & 0.71 \\
S2 $+5 \%$ & $4.02 \pm 0.08$ & $1.10 \pm 0.04$ & $0.80 \pm 0.02$ & $0.02 \pm 0.00$ & 0.999 & 0.79 \\
S2+10\% & $5.99 \pm 0.10$ & $0.98 \pm 0.04$ & $0.54 \pm 0.01$ & $0.02 \pm 0.00$ & 0.999 & 0.86 \\
S3 & $1.63 \pm 0.03$ & $0.63 \pm 0.03$ & $0.22 \pm 0.01$ & $0.01 \pm 0.00$ & 0.997 & 0.72 \\
S3+5\% & $4.28 \pm 0.07$ & $1.35 \pm 0.09$ & $0.60 \pm 0.03$ & $0.02 \pm 0.00$ & 0.998 & 0.76 \\
S3+10\% & $6.97 \pm 0.06$ & $1.46 \pm 0.10$ & $0.51 \pm 0.02$ & $0.02 \pm 0.00$ & 0.998 & 0.83 \\
S4 & $1.90 \pm 0.05$ & $1.25 \pm 0.06$ & $0.33 \pm 0.01$ & $0.02 \pm 0.00$ & 0.998 & 0.60 \\
S4+5\% & $5.63 \pm 0.08$ & $1.38 \pm 0.05$ & $0.59 \pm 0.01$ & $0.02 \pm 0.00$ & 0.999 & 0.80 \\
S4+10\% & $6.93 \pm 0.08$ & $1.19 \pm 0.04$ & $0.40 \pm 0.02$ & $0.02 \pm 0.00$ & 0.999 & 0.85 \\
S5 & $4.65 \pm 0.02$ & $1.29 \pm 0.07$ & $0.29 \pm 0.01$ & $0.02 \pm 0.00$ & 0.999 & 0.78 \\
S5+5\% & $7.96 \pm 0.11$ & $1.65 \pm 0.07$ & $0.45 \pm 0.02$ & $0.03 \pm 0.00$ & 0.999 & 0.83 \\
S5+10\% & $8.28 \pm 0.15$ & $1.53 \pm 0.08$ & $0.47 \pm 0.03$ & $0.03 \pm 0.00$ & 0.999 & 0.84 \\
\hline
\end{tabular}

S: soil; BW: bentonite waste; 5\% (Soil-Bentonite waste mixtures for increase soil carbon in a 5\%); 10\% (Soil-Bentonite waste mixtures for increase soil carbon in a $10 \%$ )

C: cumulative carbon mineralized at time $\mathrm{t}\left(\mathrm{mg} \mathrm{g}^{-1}\right.$ soil carbon); $\mathrm{t}$ : time from start of incubation (days); $\mathrm{C}_{1}$ and $\mathrm{C}_{2}$ : fast and slowly

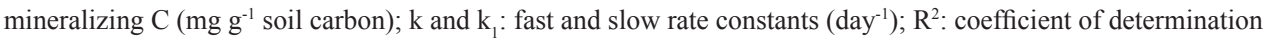

\section{Discussion}

The $\mathrm{C}$ mineralization is influenced by different soil abiotic properties such as texture (Merino et al., 2016), soil $\mathrm{pH}$ (Aciego Pietri and Brookes, 2008) or $\mathrm{C} / \mathrm{N}$ ratio (Brady and Weil, 2008). However, the microbial properties such as size, activity or composition of the soil microbial biomass have low effect on the C-mineralization (Kemmitt, et al., 2008; Brookes et al., 2017). The bentonite based organo-mineral wastes may change these abiotic properties in the soil (Loh et al., 2017), but it can be opposite effect. Thus, the increased of clay content in the soil may decreased the $\mathrm{C}$ mineralization (Pal and Marschner, 2016), whereas the expected pH increases (Fernández-Calviño et al., 2015) may increase the $\mathrm{C}$ mineralization. The lower $\mathrm{C} / \mathrm{N}$ ratio in the bentonite waste than in the soils may also contribute to $\mathrm{C}$ mineralization increases, but the presence of toxic substances such as high concentrations of $\mathrm{Cu}$ may decreased the soil respiration (Fernández-Calviño and Bååth, 2016). The $\mathrm{C}$ mineralization data (expressed as $\mathrm{mg} \mathrm{C}-\mathrm{CO}_{2}$ per gram of $\mathrm{C}$ ) was significantly lower in the bentonite waste than in the soils (Figure 1). Several mechanisms may be responsible of the less efficiency of carbon mineralization found in the bentonite waste with respect to the soils such as the presence of toxic substances such as $\mathrm{Cu}$ and salts (EC) in the waste. Fernández-Calviño and Bååth (2016) showed significant decreases of the soil respiration for total $\mathrm{Cu}$ concentrations higher than $250 \mathrm{mg} \mathrm{kg}^{-1}$, whereas Rath and Rousk (2015), showed significant decreases in soil respiration for EC values over $1 \mathrm{dS} \mathrm{m}^{-1}$. These two threshold values were clearly higher in the bentonite waste (Table 1). Also, the high presence of bentonite (clay) in the waste may cause additional C-mineralization decreases (Pal and Marschner, 2016). 
When bentonite waste was added to the soils the $\mathrm{C}$ mineralization increased in proportions between 68 and $337 \%$ (Figure 1), suggesting a significant positive priming effect (Kuzyakov et al., 2000); i.e., an increase in soil organic carbon mineralization in the amended soils relative to the carbon mineralization was observed in the soils and bentonite waste separately. In fact, the $\mathrm{C}$ mineralization in the soil-bentonite waste mixtures was between 75 and $370 \%$ higher than the weighted sum of the respiration observed for the soil and waste individually (Figure 2).

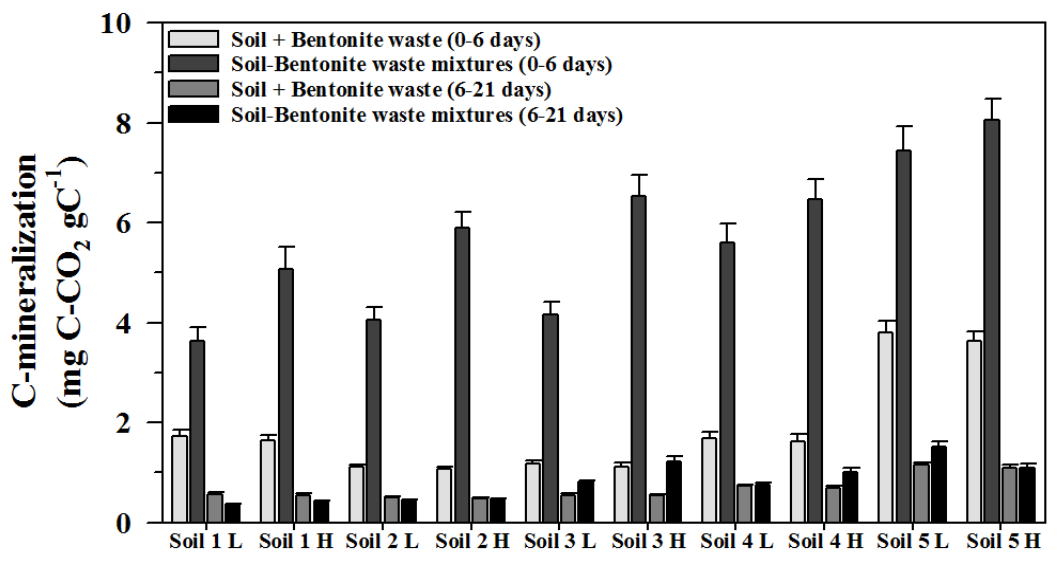

Figure 2. Comparison among $\mathrm{C}$ mineralization in the soil-bentonite waste mixtures with the sum of $\mathrm{C}$ mineralization in soils and bentonite waste separately for different periods: 0-6 days and 6-21. The codes on the x-axis are the numbers of each soil under study accompanied by the letters $\mathrm{L}$ or $\mathrm{H}$ representing the dose of bentonite waste added to increase the native total soil organic carbon content by $5 \%$ and $10 \%$, respectively. The columns show the mean values and the error bars the standard errors.

The high positive priming effects found in the present work may be due to the presence of more bioavailable organic matter in the bentonite waste than the native soil organic matter (lower $\mathrm{C} / \mathrm{N}$ ratio; Table 1) because substrate availability is one of the most important factors controlling soil organic matter decomposition (Uchida et al., 2012). However, as we showed previously, a lower $\mathrm{C}$ mineralization was found in the bentonite waste respect to the nonamended soils. This lower $\mathrm{C}$ mineralization may therefore be attributed to the presence of high concentrations of toxic substances in the bentonite waste for the microbial communities.
The salinity and available $\mathrm{Cu}$ concentrations in this type of waste are high (Table 1), and therefore, they can inhibit microbial activity in the waste. However, when the bentonite waste was mixed with an acidic soil, the salinity in the soil-bentonite waste mixtures decreased (Fernández-Calviño et al., 2015), and the $\mathrm{Cu}$ availability decreased until it reached acceptable values (Arias-Estévez et al., 2007). Also, the addition of bentonite waste to acid soils generally increase the $\mathrm{pH}$ (Fernández-Calviño et al., 2015; RodríguezSalgado et al., 2017), and therefore it can favour the C-mineralization (Aciego Pietri and Brookes, 2008). Therefore, the addition of bentonite waste to acidic 
soils (to increase the soil organic carbon between 5 and $10 \%$ ) has no negative effects on $\mathrm{C}$ mineralization after 21 incubation days due to the dilution of toxic substances in the soil or adsorption processes of these substances (Fernández-Calviño et al., 2015). This result was in accordance with a previous work where an enzymatic activity related with the $\mathrm{C}$-cycle was no negatively affected by the addition of a similar bentonite waste (Rodríguez-Salgado et al., 2017). Thus, negative effects on short-term organic matter turnover will be not expected after soil amendment with bentonite wastes, despite negative effects on other biological properties were observed previously in an acidic soil, such as for phosphomonoesterase enzymatic activity (Rodríguez-Salgado et al., 2017). The cumulative quantities of $\mathrm{C}-\mathrm{CO}_{2}$ (Figure 1) were fitted satisfactorily by the special model (Equation 1), explaining more than $99 \%$ of the experimental results in all cases (Table 2). This model previously offered the most appropriate description of the cumulative $\mathrm{C}-\mathrm{CO}_{2}$ evolution data in soils (Bernal et al., 1998; Saviozzi et al., 2014). The special model is a combination of two different kinetic equations, which suggest that the organic carbon content of the soils consisted of two fractions with different degrees of biodegradability (Bernal et al., 1998). Table 2 shows the special model fitted parameters for bentonite waste, soils and soil-bentonite waste mixtures. The proportion of fast mineralized carbon was $25 \%$ in the bentonite waste, whereas in the non-amended soils, it ranged from 60 to $78 \%$. These results showed that the carbon mineralization in the bentonite waste was dominated by the slow process, whereas in the non-amended soils, the fast $\mathrm{C}$ mineralization processes are prevalent. However, when the bentonite waste was added to the soil, the proportion of $\mathrm{C}$ mineralized via fast processes was even higher than that in the non-amended soils. The initial and quick $\mathrm{C}$ mineralization in amended soils with organic wastes was previously observed (Bustamante et al., 2007) and attributed to the amount of C present initially in soluble form, the labile $\mathrm{C}$ fraction (Trinsoutrot et al., 2000; Bernal et al., 1998). However, in the non-amended soils, we also observed a fast $\mathrm{C}$ mineralization. Another possibility is that the high $\mathrm{C}$ mineralization in soils and in bentonite waste amended soils may be associated to the formation of microbial hotspots promoting hot moments, i.e., short-term events inducing accelerated process rates compared to the average rates (Kuzyakov and Blagodatskaya, 2015).

In the non-amended soils, these "events" may be the rewetting process which can activate dormant microorganisms (Thomsen et al., 1999), whereas in amended soils the rewetting effect may be reinforced by a high input of labile carbon in the soil supply by the bentonite waste, an important event that favours the hotspots activity and thus drives the hot moments (Kuzyakov and Blagodatskaya, 2015). However, in the bentonite waste the presence of hotspots driving hot moments may be limited by the negative effect of high concentrations of salts and copper (Table 1) on microbial communities. Therefore, the $\mathrm{C}$ mineralization in the bentonite waste is produced mainly via slow processes. After the initial increase of carbon mineralization, the evolution of the specific respiration tended to be similar to that of the control soils (Bustamante el al., 2007), as in the present work, where the priming effects were observed mainly during the first 6 incubation days, whereas for longer incubation times, they were almost negligible (Figure 2). These results seem to be in accordance with the formation of microbial hotspots that are active during short-term hot moments and clearly indicated that the addition of bentonite can have important short-term implications in the $\mathrm{C}$ cycle of the vineyard soils. 


\section{Conclusions}

The addition of a bentonite winery waste, rich in organic matter, nutrients, salinity and copper, to acid vineyard soils at amounts equivalent up to $10 \%$ of the native $\mathrm{C}$, did not induced decreases on $\mathrm{C}$-mineralization after 21 incubation days. Therefore negative effects on short-term organic matter turnover will be not expected after the addition of bentonite based winery wastes in acid soils.

\section{Acknowledgements}

This work was supported by the Consellería de Medio Rural from Xunta de Galicia (FEADER2009-22) through the CO-106-09 contract between the Soil Science and Agricultural Chemistry Area of the University of Vigo and Bodegas Cunqueiro. The financial support of CIA3 through FEDER funds under the program of Consolidation and Arrangement of Research Units from Consellería de Educación (Xunta de Galicia) is also acknowledged. P. Pérez-Rodríguez is funded by the FPU program from the Spanish Ministry of Education.

\section{References}

Aciego Pietri, J.C., Brookes, P.C. 2008. Relationships between soil $\mathrm{pH}$ and microbial properties in a UK arable soil. Soil Biol. Biochem. 40, 1856-1861.

Arias-Estévez, M., López-Periago, E., Nóvoa-Muñoz, J.C., Torrado-Agrasar, A., Simal-Gándara, J. 2007. Treatment of an acid soil with bentonite used for wine fining: effects on soil properties and the growth of Lolium multiflorum. J. Agric. Food Chem. 55, 7541-7546.

Bernal, M.P., Sánchez-Monedero, M.A., Paredes, C., Roig, A. 1998. Carbon mineralization from organic wastes at different composting stages during their incubation with soil. Agric. Ecosyst. Environ. 69, 175-189.

Bertsch, P.M., Bloom, P.R. 1996. Aluminum. In: D.L. Sparks, (ed). Methods of Soil Analysis Part 3. Chemical Methods. Soil Science Society of America, Madison, pp: 517-550.

Brady, N.C., Weil, R.R. 2008. The Nature and Properties of Soils, 14th ed. Pearson-Prentice Hall, Upper Saddle River, NJ, USA.

Brookes, P.C., Chen, Y.F., Chen, L., Qiu, G., Luo, Y., $\mathrm{Xu}, \mathrm{J}$. 2017. Is the rate of mineralization of soil organic carbon under microbiological control? Soil Biol. Biochem. 112, 127-139.

Bustamante, M.A., Pérez-Murcia, M.D., Paredes, C., Moral, R., Pérez-Espinosa, A., Moreno-Caselles, J. 2007. Short-term carbon and nitrogen mineralisation in soil amended with winery and distillery organic wastes. Bioresour. Technol. 98, 3269-3277.

Bustamante, M.A., Said-Pullicino, D., Paredes, C., Cecilia, J.A., Moral, R. 2010. Influences of winery-distillery waste compost stability and soil type on soil carbon dynamics in amended soils. Waste Manage. 30, 1966-1975.

Fernández-Calviño, D., Rodríguez-Salgado, I., PérezRodríguez, P., Nóvoa-Muñoz, J.C., Arias-Estévez, M. 2015. Time evolution of the general characteristics and $\mathrm{Cu}$ retention capacity in an acid soil amended with a bentonite winery waste. J. Environ Manage. 150, 435-443.

Fernández-Calviño, D., Bååth, E. 2016. Interaction between $\mathrm{pH}$ and $\mathrm{Cu}$ toxicity on fungal and bacterial performance in soil. Soil Biol. Biochem. 96, 20-29.

Ginocchio, R., Cárcamo, V., Bustamante, E., Trangolao, E., de la Fuente, L.M., Neaman, A. 2013. Efficacy of fresh and air-dried biosolids as amendments for remediation of acidic and metal-polluted soils: A short-term laboratory assay. J. Soil Sci. Plant Nutr. 13, 855-869. 
Hasbullah, H., Marschner, P. 2016. Effect of residue mixtures on response of cumulative respiration to salinity. J. Soil Sci. Plant Nutr. 16, 323-336.

Kemmitt, S., Lanyon, C., Waite, I., Wen, Q., Addiscott, T., Bird, N., O’Donnell, A.G., Brookes, P.C. 2008. Mineralization of native soil organic matter is not regulated by the size, activity or composition of the soil microbial biomass-a new perspective. Soil Biol. Biochem. 40, 61-73.

Kuzyakov, Y., Friedel, J.K., Stahr, K. 2000. Review of mechanism and quantification of priming effects. Soil Biol. Biochem. 32, 1485-1498.

Kuzyakov, Y., Blagodatskaya, E. 2015. Microbial hotspots and hot moments in soil: Concept \& review. Soil Biol. Biochem. 83, 184-199.

Li, Y.T., Rouland, C., Benedetti, M., Li, F.B., Pando, A., Lavelle, P. 2009. Microbial biomass, enzyme and mineralization activity in relation to soil organic $\mathrm{C}, \mathrm{N}$ and $\mathrm{P}$ turnover influenced by acid metal stress. Soil Biol. Biochem. 41, 969-977.

Loh, S.K., Cheong, K.Y., Salimon, J. 2017. Surfaceactive physicochemical characteristics of spent bleaching earth on soil-plant interaction and water-nutrient uptake: A review. Appl. Clay Sci. 140, 59-65.

Meisner, A., Bååth, E., Rousk, J. 2013. Microbial growth responses upon rewetting soil dried for four days or one year. Soil Biol. Biochem. 66, 188-192.

Meli, S., Porto, M., Belligno, A., Bufo, S.A., Mazzatura, A. Scopa, A. 2002. Influence of irrigation with lagooned urban wastewater on chemical and microbiological soil parameters in a citrus orchard under Mediterranean condition. Sci. Total Environ. 285, 69-77.

Merino, C., Godoy, R., Matus, F. 2016. Soil enzymes and biological activity at different levels of organic matter stability. J. Soil Sci. Plant Nutrit. 16, 14-30.
Mosse, K.P.M., Patti, A.F., Smernik, R.J., Christen, E.W., Cavagnaro, T.R. 2012. Physicochemical and microbiological effects of long- and shortterm winery wastewater application to soils. J. Hazard. Mater. 201-202, 219-228.

Nannipieri, P., Ascher, J., Ceccherini, M.T., Landi, L., Pietramellara, G., Renella, G. 2003. Microbial diversity and soil functions. Eur. J. Soil Sci. 54, 655-670.

Pal, S., Marschner, P. 2016. Influence of clay concentration, residue $\mathrm{C} / \mathrm{N}$ and particle size on microbial activity and nutrient availability in clay amended sandy soil. J. Soil Sci. Plant Nutrit. 16, 350-361.

Rath, K.M., Rousk, J. 2015. Salt effects on the soil microbial decomposer community and their role in organic carbon cycling: A review. Soil Biol. Biochem. 81, 108-123.

Rodríguez-Salgado, I., Paradelo-Pérez, M., PérezRodríguez, P., Cutillas-Barreiro, L., FernándezCalviño, D., Nóvoa-Muñoz, J.C., Arias-Estévez, M. 2014. Cyprodinil retention on mixtures of soil and solid wastes from wineries. Effects of waste dose and ageing. Environ. Sci. Pollut. Res. 21, 9785-9795.

Rodríguez-Salgado, I., Pérez-Rodríguez, P., GómezArmesto, A., Díaz-Raviña, M., Nóvoa-Muñoz, J.C., Arias-Estévez, M., Fernández-Calviño, D. 2017. Modification of chemical properties, $\mathrm{Cu}$ fractionation and enzymatic activities in an acid vineyard soil amended with winery wastes: A field study. J. Environ. Manage. 202, 167-177.

Saviozzi, A., Vanni, G., Cardelli, R. 2014. Carbon mineralization kinetics in soils under urban environment. Appl. Soil Ecol. 73, 64-69.

Sumner, M.E., Miller, W.P. 1996. Cation exchange capacity and exchange coefficients. In: D.L. Sparks (ed). Methods of Soil Analysis Part 3, Chemical Methods. Soil Science Society of America, Madison, pp. 1201-1229. 
Thomsen, M., Faber, J.H., Sorensen, P.B. 2012. Soil Ecosystem health and services - Evaluation of ecological indicators susceptible to chemical stressors. Ecol. Indic. 16, 67-75.

Thomsen, I.K., Schjonning, P., Jensen, B., Kristensen, K., Christensen, B.T. 1999. Turnover of organic matter in differently textured soils II. Microbial activity as influenced by soil water regimes. Geoderma 89, 199-218.
Trinsoutrot, I., Recous, S., Bentz, B., Linères, M., Chèneby, D., Nicolardot, B. 2000. Biochemical quality of crop residues and carbon and nitrogen mineralization kinetics under nonlimiting conditions. Soil Sci. Soc. Am. J. 64, 918-926.

Uchida, Y., Nishimura, S., Akiyama, H. 2012. The relationship of water-soluble carbon and hot-watersoluble carbon with soil respiration in agricultural fields. Agric. Ecosyst. Environ. 156, 116-122. 